http://journal.uinsgd.ac.id/index.php/biodjati

\title{
THE CAPABILITY OF CONSORTIUM PHOSPHATE SOLUBILIZING BACTERIA AND IAA PRODUCING FUNGI ON PROMOTING ELEPHANT GRASS GROWTH
}

\author{
Witiyasti Imaningsih*1, Anang Kadarsah ${ }^{2}$, Raden Dwi Thriwantho Rusmannurrachmad
}

Received : March 06, 2019

Accepted : April 19, 2019

\section{DOI: $10.15575 /$ biodjati.v4i1.4284}

${ }^{1}$ Biology Study Program, Mathematics and Science Faculty of Universitas Lambung Mangkurat. Jl. Unlam III Komplek Unlam Banjarbaru, Kaliman$\tan$ Selatan-70714

${ }^{2}$ Microbiology Laboratory, Mathematic and Science Faculty Laboratory, Universitas Lambung Mangkurat. Jl. A.Yani Km. 36.00, Banjarbaru, Kalimantan Selatan-70714

e-mail:

*1witiyastiimaningsih@unlam.ac.id 2anangunlam@gmail.com

하n.03100@gmail.com

*Corresponding author
Abstract. Phosphorus compound in the critical land is relatively low that caused phosphorus is bonded to metals. The isolate BRC-AP and BRC-AK are a phosphate solubilizing bacteria (PSB) indigenous critical land that has the ability to dissolve phosphate. The used of phosphate solubilizing bacteria are able to improve plant growth on critical lands. The aimed of this study was to measure the growth rate of shoot length, root length and biomass of root, and leaf cuttings elephant grass (Pennisetum purpureum cv. King Grass) which inoculated with the consortium of phosphate solubilizing bacteria and IAA producing fungi. Phosphate dissolving activity is determined by the formation of clear zone in solid Pikovskaya medium, synergism assay between bacteria and fungi observed on SDA medium then proceed testing the ability of bacteria and fungi consortium to promote plant growth. The result showed that the highest of phosphate solubility index was found in isolate BRC-AP (27), addition of the combination of isolate BRC-AP, BRC-AK and Humicola sp. R.Dn have significant effect on shoot growth in the first week and leaf dry weight. The highest length shoot of cutting elephant grass was found in treatment with the consortium of phosphate solubilizing bacteria and IAA producing fungi $(B R C-A P+B R C-A K+K P)(58.66 \mathrm{~cm})$. The highest of leaf dry weight was found in treatment with $B R C-A P+B R C-A K+K P(5.65$ gr). The addition of consortium phosphate solubilizing bacteria and IAA producing fungi from South Kalimantan critical land proved can improve plant growth especially length shoot and leaf dry weight.

Keywords: elephant grass, IAA producing fungi, phosphate solubilizing bacteria

\section{Citation}

Imaningsih, W., Kadarsah, A. \& Rusmannurrachmad, R. D. T. (2019). The Capability of Consortium Phospate Solubilizing Bacteria and IAA Producing Fungi on Promoting Elephant Grass Growth. Jurnal Biodjati, 4(1), 138-148

\section{INTRODUCTION}

One of the areas in South Kalimantan with the large critical land area is in Cempaka District Banjarbaru, due to mining activities. This activity causing the land cannot be over- grown plants generally. Some plants grow through with long adaptation process. Critical land revegetation can be done by using elephant grass (Pennisetum purpureum cv King Grass) plants. According to Magcale-Macardog et al. (2008), elephant grass can be used 


\section{JURNAL BIDDJATI}

http://journal.uinsgd.ac.id/index.php/biodjati

as an antidote to erosion, degradation and soil damage. In addition, according to Sinaga (2008), elephant grass is able to withstand the condition of land that lack air due to the ability of elephant grass in improving the efficiency of air use.

Mining activities cause metals to accumulate on the ground and have an impact on the availability of nutrients. Soils that have high metal content will affect nutrient mobility such as phosphorus. Phosphorus (P) will bind to the metal compounds in the form of Ca-P, Mg-P, Al-P and Fe-P According to (Fluck et al., 1998). The presence of the P-bonds causes P not available to the plant. One alternative to overcome the low P-available on the soil is by utilizing the phosphate solubilizing bacteria (PSB) (Atekan et al., 2014). The ability of PSB in producing organic acids such as citric acid, sulfuric acid, nitric acid and oxalic acid can dissolve the phosphate bound (Hilda \& Faga, 2000).

The use of PSB is one of the efforts to stimulate the growth of plants in critical land. Based on the preliminary test, two isolates of phosphate solubilizing bacteria from Cempaka Banjarbaru critical land were coded BRCAP (white acacia rhizosphere bacteria from Cempaka) and BRC-AK (yellow acacia rhizosphere bacteria from Cempaka). PSB inoculum from critical land more effective tackling of critical land when compared to the same inoculum but not from critical land. Egamberdiyeva et al. (2006) reported the inoculation of PSB such as Pseudomonas able to increase the growth of wheat, corn and cotton plants. In addition, to stimulate the growth of plants in critical land is needed plant growth promoting microorganisms such as plant growth IAA (indole acetic acid). Fungi producer Imaningsih \& Zulaikha (2013) showed that crude extract of fungi from Cempaka Banjarbaru critical land is able to increase elephant grass growth on critical soil because it contains growth regulator components such as IAA and kinetin. Imaningsih (2010) reports that some litter species of litter in industrial plantation forest areas in some areas of Central Kalimantan and East Kalimantan can produce growth regulators that increasing the number of lateral roots and dry weight of mung bean (Vigna radiata (L.) R. Wilczek) plants.

The combination of phosphate solubilizing and IAA producing bacteria is considered more effective in spurring plant growth on critical land. Budi et al. (2011) reports on the use of rhizosphere bacteria and endophytic fungi can maximize the growth of rice crops and increase plant resistance. The results of Gerhardson et al. (2008) study, indicating the presence of double inoculation of bacteria and fungi in plants can have a positive effect on plant growth and productivity.

Based on this, critical land revegetation can be maximized by utilizing a consortium between phosphate solubilizing bacteria and IAA-producing fungi from critical land to spur the growth of elephant grass (Pennisetum purpureum cv King Grass). Therefore, the aim of this study is for testing of the potential phosphate solubilizing bacteria and IAA-producing fungi from critical land of Cempaka Banjarbaru South Kalimantan to support the growth of elephant grass in the effort to critical land revegetation.

\section{MATERIALS AND METHODS}

\section{Measurement of Solubility Index of BRC- AP and BRC-AK Isolates in a Solid Picov- skaya Medium.}

Phosphate dissolving activity is determined by the formation of clear zone in solid Pikovskaya medium (Rao, 1994). The medium composition : $20 \mathrm{~g} / \mathrm{L}$ agar, $0.5 \mathrm{~g} / \mathrm{L}$ yeast extract, $10 \mathrm{~g} / \mathrm{L}$ dextrose, $5 \mathrm{~g} / \mathrm{L} \mathrm{Ca}\left(\mathrm{PO}_{4}\right)_{2}$, 


\section{JURNAL BIDDJATI}

http://journal.uinsgd.ac.id/index.php/biodjati

$0.5 \mathrm{~g} / \mathrm{L}\left(\mathrm{NH}_{4}\right)_{2} \mathrm{SO}_{4}, 0.2 \mathrm{~g} / \mathrm{L} \mathrm{KCl}, 0.1 \mathrm{~g} / \mathrm{L} \mathrm{Mg}$ $\mathrm{SO}_{4} \cdot 7 \mathrm{H}_{2} \mathrm{O}, 0.01 \mathrm{~g} / \mathrm{L} \mathrm{MnSO}_{4}$ and $0.01 \mathrm{~g} / \mathrm{L}$ $\mathrm{FeSO}_{4}$. The form of a clear zone ratio (halo zone) by comparing the diameter of the clear zone and the diameter of the colony was measured (Khan et al., 2014). Clear zone diameters and measured colonies were then calculated using the phosphate solubility index formula where the diameter of the colony plus the diameter of the clear zone divided by the diameter of the colony (Malviya et al., 2011).

\section{Synergism Assay Between Phosphate Sol- ubilizing Bacteria (PSB) and IAA-Produc- ing Fungi from Critical Land.}

The BRC-AP and BRC-AK isolates were tested for activity with IAA-producing fungi from Cempaka Banjarbaru Humicola sp. R.Dn., by growing PSB and IAA-producing fungi on Sabouraud Dextrose agar medium in petri dish simultaneously. PSB isolates were previously grown for 2 days before fungi, then incubated at $25-30^{\circ} \mathrm{C}$ for 72 hours. Observations were made by measuring the radius of the fungal colonies. The measurement data was then calculated to find the percentage of resistance using the percentage formula of resistance where the radius of the colonies grown in the opposite direction of the bacterial colony was reduced by the radius of the fungal colonies that sprouted toward the bacterial colony divided by the radius of the fungal colony that grew in the opposite direction of bacterial colonies then multiplied by $100 \%$ (Skidmore, 1976).

Testing the Ability of Consortium of Phosphate Solubilizing Bacteria (PSB) and IAA-Producing Fungi from Critical Land in Spurring the Growth of Elephant Grass Cuttings.
The application consists of several stages including the production of inoculants phosphate solubilizing bacterial in liquid Pikovskaya medium and the manufacture of IAA-producing fungi from critical land. Furthermore, each suspension $(15 \mathrm{~mL}: 34.12 \times$ $108 \mathrm{sel} / \mathrm{ml}$ for Humicola sp. R.Dn and one inoculating loop for PSB), was applied to the test media, which is 500 grams of sterile soil from the critical land which was put into the polybags and planted whit the elephant grass cuttings. Addition of The inoculation treatment consisted of (Control: without addition of inoculum), (BRC-AP: PSB 1), (BRC-AK: PSB 2), (KP: IAA-producer isolate Humicola sp. R.Dn.), BRC-AP + KP (combination of PSB $1+$ Humicola sp. R.Dn), BRC-AK $+\mathrm{KP}$ (combination of PSB $2+$ Humicola sp. R.Dn), BRC-AP + BRC-AK + KP (combination of PSB $1+$ PSB $2+$ Humicola sp. R.Dn). The observed data were the increase of shoot length in each week after planting, root length and root biomass and leaves.

\section{Data Analysis}

The experimental design of this study used a complete randomized design (RAL) with one test plant and seven treatments. Each treatment was repeated three times so that 21 units of the experiment were obtained (Ahmed \& Hasnain, 2010). The observed responses were an increase of shoot length, root length, and root biomass and leaves. The data obtained were analyzed statistically by analysis of variance. The different treatments were significantly tested further using Duncan's Multiple Range Test (DMRT). The test was performed at 95\% confidence level (significant $\mathrm{P}<0.05$ ) using SPSS (Statistical Package for the Sciences System) version 17. 


\section{JURNAL BIDDJATI}

http://journal.uinsgd.ac.id/index.php/biodjati

\section{RESULTS AND DISCUSSION}

\section{Phosphate Solubility Index of Phosphate Solubilizing Bacteria from Critical Land in a Solid Pikovskaya Medium.}

The highest value of phosphate solubility index was shown on BRC-AP isolate (27) in ten days incubation. While on BRC$\mathrm{AK}$ isolate, the highest phosphate solubility index (26.6) at nine days incubation (Table 1). The ability of bacteria on dissolving phosphate is bound due to bacteria capable of producing organic acids such as oxalate, succinate, tartrate, citrate, lactate, $\alpha$-ketoglutarate, acetate, formate, propionate, glycolate, glutamate, glyoxylate, malate, and fumarate. These organic acids are able to release bonded phosphate bonds becomes dissolved (Hilda \& Faga, 2000). In addition, the ability of bacteria in producing enzyme phosphatase is considered capable of dissolving the phosphate bonds. Some of the resulting phosphatase enzymes include phosphomonoesterase, phosphodiesterase, triphosphomonoesterase and phosphoamidase.

Table 1. The phosphate solubility index values of BRC-AP and BRC-AK isolates on solid Pikovskaya medium

\begin{tabular}{ccccc}
\hline \multirow{2}{*}{ Isolate } & \multicolumn{5}{c}{ Day } \\
\cline { 2 - 5 } & 7 & 8 & 9 & 10 \\
\hline BRC-AP & 26.6 & 25 & 25.6 & 27 \\
BRC-AK & 25.9 & 25.9 & 26.6 & 24.8 \\
\hline
\end{tabular}

Description: the average of 2 repetitions

These enzymes are capable of hydrolyzing organic phosphates into inorganic phosphates $\left(\mathrm{H}_{2} \mathrm{PO}^{4-}, \mathrm{HPO}^{4+}\right)$ (Khan et al. (2014); Meatyard (1999))
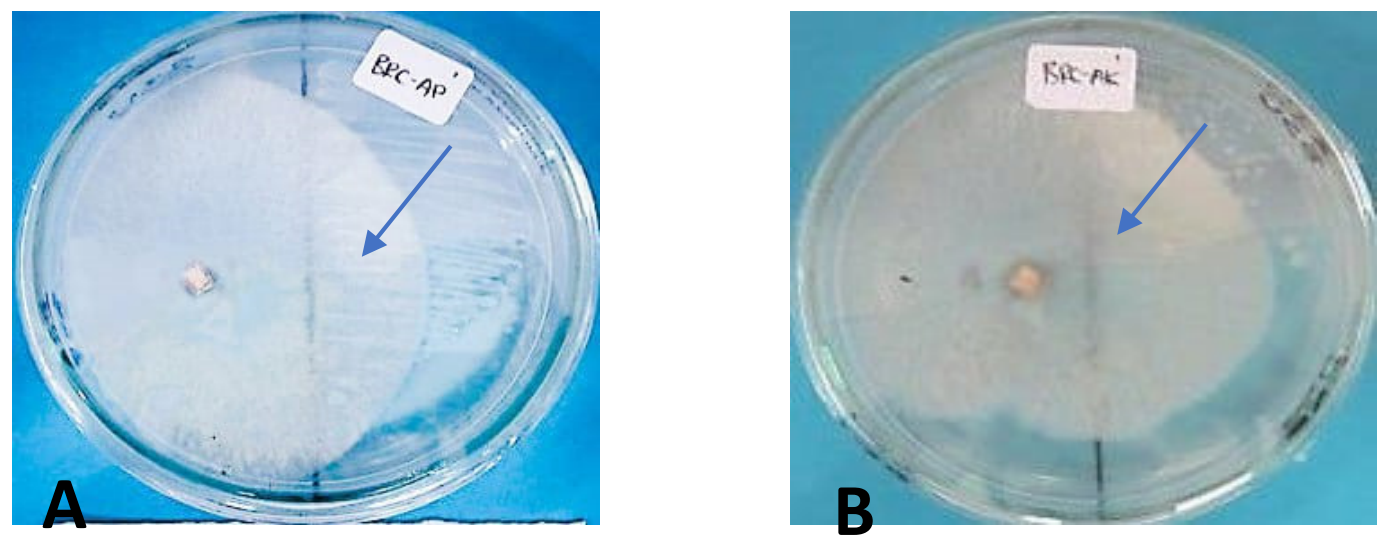

Figure 1. Synergism between BRC-AP (A) and BRC-AK (B) isolates with IAA-producing fungi (Humicola sp .R.Dn from critical land. The arrows show the location of bacterial colonies 


\section{JURNAL BIDDJATI}

http://journal.uinsgd.ac.id/index.php/biodjati

Percentage inhibition showed the inhibition rate of fungi against BRC-AP isolates is (-)55.02\% and BRC-AK (-)76\%. A percent value between 0 to negative (-) indicates no inhibition between fungi and bacteria. The synergism test between isolate phosphate solubilizing bacteria (BRC-AP and BRC-AK) with IAA- producing fungi (Humicola sp. R.Dn) showed that both isolates were able to coexist. Both bacterial and fungi isolates did not interfere with each other's growth (Figure 1).

According to Sudantha et al. (2011) testing of antagonism and synergism between microorganisms can be seen through the percentage of obstacles. If the percentage is 0 or less than 0 , it can be said microorganisms are not antagonistic. Santos et al. (2008), that synergism testing between two or more different microorganisms is indicated by the inhibition of the inhibition zone between colonies.

\section{Effect of the Consortium of Phosphate Solubilizing Bacteria and IAA-Producing Fungi from Critical Land to the Growth Rate of Elephant Cuttings Bud Length at 1 to 3 Weeks After Planting}

Observation of the growth rate of shoot length at one to three weeks after planting shows a difference every week. The first week showed relatively long shoot, while in the second and third weeks the growth rate of shoot length decreased (Table 2). The results of the statistical analysis using ANOVA test on the measurement of the first week have a significant effect on the growth of shoot length. This suggests that treatment of consortium of PSB with IAA producing fungi gives different results compared to the single treatment (without PSB) and control (no treatment). While in the second and third weeks the rate of growth of shoot length did not have a significant effect.

The treatment with the highest increase in BRC-AP + BRC-AK + KP is $58.66 \mathrm{~cm}$. The measurement result of shoot length growth at two weeks after planting increased from one week after planting. Based on statistical analysis the treatment did not have a significant effect on the growth of shoot length. The BRC-AP + BRC-AK + KP treatment was treated with the highest increase $(8 \mathrm{~cm})$ with a shoot length of $66.66 \mathrm{~cm}$ (Table 2). The result of shoot length at three weeks after planting increased from two weeks after planting. Based on statistical analysis the treatment did not have a significant effect on the growth of shoot length. The treatment with the highest increase was in BRC-AP + KP treatment $(27.66 \mathrm{~cm})$ with a shoot length of $82.66 \mathrm{~cm}$ (Table 2).

Hussain et al. (2013) showed that the inoculation of phosphate solubilizing bacteria was able to increase the growth rate of corn compared with the PSB inoculation. This is also reinforced by Aryantha et al. (2004) that inoculation of IAA-producing microbes can increase the growth of green bean sprouts. The treatment of PSB and IAA producing fungi consortium showed that the treatment had gave the best effect on the growth rate of shoot length compared with a single or no treatment. Wuriesyliane et al. (2013) showed the inoculation of providing nutrient bacterial consortium contribute the best yields on rice crops.

The difference in the rate of growth of the long shoots on each week was brought about due to several factors such as the content of supplementary feeding, rooting, and plant growth regulator. The rate of growth in length of shoots in the first week of relatively rapid because of the food reserve in the tissues of cuttings is still available. Consortium of PSB and IAA producing fungi give nutrients and growing regulatory substances. According to Ardaka et al. (2007); and Sutatar \& Sanjaya (1996) factors that influence the growth of shoots on cuttings i.e. humidity, 


\section{JURNAL BIDDJATI}

http://journal.uinsgd.ac.id/index.php/biodjati

temperature, light intensity, the rooting medium, plant growth factor, water availability, food reserve, plant age, season, and the time of the taking of cuttings.

The results of the measurement of the rate of growth of the long shoots in the second week was decline. This is because food reserves in the tissues of cuttings are decrease. Additionally, on the second week of root cut- tings started to grow so that the cuttings start doing taking nutrition from the growth medium. Next on the third week of growth rate experienced a slight increase. This is because the cuttings are able to utilize the nutrients derived from growth medium. According to Keesey \& Lerner (-) cuttings use energy to form new roots, most of the energy comes from photosynthesis if the cutting has leaves.

Table 2. Shoot length growth of elephant grass cuttings at one to three weeks after planting $(\mathrm{cm})$.

\begin{tabular}{lccc}
\hline \multirow{2}{*}{ Treatment } & \multicolumn{3}{c}{ Age } \\
\cline { 2 - 4 } & 1 WAP & 2 WAP & 3 WAP \\
\hline Control & $31.13 \pm 8.82 \mathrm{a}$ & $5.2 \pm 2.36 \mathrm{a}$ & $8 \pm 6.16 \mathrm{a}$ \\
BRC-AP & $56.66 \pm 6.94 \mathrm{~b}$ & $7.66 \pm 2.49 \mathrm{a}$ & $16.66 \pm 6.51 \mathrm{a}$ \\
BRC-AK & $54.73 \pm 8.79 \mathrm{~b}$ & $5.96 \pm 1.51 \mathrm{a}$ & $20.96 \pm 5.66 \mathrm{a}$ \\
KP & $44.16 \pm 8.61 \mathrm{a}$ & $5.93 \pm 1.31 \mathrm{a}$ & $16.4 \pm 9.20 \mathrm{a}$ \\
BRC-AP + KP & $50.13 \pm 5.06 \mathrm{~b}$ & $4.86 \pm 0.66 \mathrm{a}$ & $27.66 \pm 8.72 \mathrm{a}$ \\
BRC-AK + KP & $50.76 \pm 8.34 \mathrm{~b}$ & $6.56 \pm 2.54 \mathrm{a}$ & $15 \pm 5.52 \mathrm{a}$ \\
BRC-AP + BRC-AK + KP & $58.66 \pm 4.71 \mathrm{~b}$ & $8 \pm 2.16 \mathrm{a}$ & $20 \pm 8.44 \mathrm{a}$ \\
\hline
\end{tabular}

The number followed by the same letter in the column shows no different at the $5 \%$ level of the DMRT test. (Control: without the addition of inoculum). (BRC-AP: phosphate solubilizing bacterial isolate 1). (BRC-AK: phosphate solubilizing bacterial isolate 2). (KP: IAA-producing isolate Humicola sp. R.Dn (WAP: week after planting). BRC-AP + KP (combination of PSB $1+$ Humicola sp.R.Dn). BRC-AK + $\mathrm{KP}$ (combination of PSB $2+$ Humicola sp .RDn). BRC-AP + BRC -AK + KP (combination of PSB 1 + PSB $2+$ Humicola sp. R.Dn)

Effect of the Consortium of PSB and IAA Producing Fungi from Critical Land to Growth of Elephant Grass Root Length.

The results of statistical analysis of root length growth using ANOVA test showed that the treatment did not have significant to on the growth of root length of elephant grass cuttings. The treatment with the highest value was shown in the BRC-AP treatment with a root length of $35.5 \mathrm{~cm}$ (Table 3).

Single PSB treatment gave the highestresult compared the combination treatment with IAA producing fungi and single IAA producing fungi. This is probably because IAA concentration that produce by fungi inhibit root growth. According to Overvoorde et al. (2010) high or above normal auxin concentrations can be inhibitors for root plant growth because enzymes cannot use these concentrations. Indole acetic acid-tryptophan mono-oxygenase is one of several enzymes that is affected by auxin concentration (Olatunji et al., 2017).

IAA from fungi as exogenous auxin may affect endogenous auxin metabolism. Studies of IAA biosynthesis have shown exogenous free IAA may have reduced biological activity in large part (Ribnicky et al., 1996). The presence of exogenous IAA caused apparent feedback inhibition of IAA biosynthesis (Tam et al., 1995). 


\section{JURNAL BIDDJATI}

http://journal.uinsgd.ac.id/index.php/biodjati

Table 3. The growth of elephant grass root length 3 weeks after planting

\begin{tabular}{lc}
\hline \multicolumn{1}{c}{ Treatment } & Root length $(\mathrm{cm})$ \\
\hline Control & $25.70 \pm 7.15 \mathrm{a}$ \\
BRC-AP & $35.50 \pm 8.84 \mathrm{a}$ \\
BRC-AK & $27.33 \pm 3.86 \mathrm{a}$ \\
KP & $30.17 \pm 10.59 \mathrm{a}$ \\
BRC-AP + KP & $28.17 \pm 7.31 \mathrm{a}$ \\
BRC-AK + KP & $31.83 \pm 6.64 \mathrm{a}$ \\
BRC-AP + BRC-AK + KP & $30.00 \pm 4.08 \mathrm{a}$ \\
\hline
\end{tabular}

The number followed by the same letter in the column shows no different at the 5\% level of the DMRT test. (control: without the addition of inoculum). (BRC-AP: PSB isolate 1). (BRC-AK: PSB isolate 2). (KP: IAA producer isolate Humicola sp. R.Dn). BRC-AP + KP (combination of PSB $1+$ Humicola sp. R.Dn). BRC-AK + KP (combination of PSB 2 + Humicola sp .R.Dn). BRC-AP + BRC-AK + KP (combination of PSB $1+$ PSB $2+$ Humicola sp. R.Dn)

Effect of the Consortium of PSB and IAA-Producing Fungi from Critical Land to Root and Leaf Biomass of Elephant Grass

The highest root dry weight was shown in BRC-AP treatment. The average dry weight of roots at the treatment was 2.12 gr. The highest dry leaf weight was found in BRC-AP + BRC-AK + KP treatment (5.65 gr). The result of statistical analysis using ANOVA test showed that the treatment had a significant effect to leaf dry weight.

While for dry weight of root treatment was not significantly effect (Table 4). Research of Hameeda (2006) showed that PSB inoculation was able to increase of corn biomass. In addition inoculation of IAA-producing fungi is also considered to play a role in increasing biomass production. IAA that produced by fungi able to accelerate the growth of shoots and roots so that the production of leaves and roots biomass to be increased. This is also reinforced by the study of Hussain (2013) suggesting that inoculation of PSB may increase the dry weight of roots, stems, and leaves of corn plants.
Treatment Rating of the Consortium of PSB and IAA-Producing Fungi from Critical Land as the Trigger of Elephant Grass Cultivation Growth.

Based on all result which includes of the highest shoot length increase, root length, root and leaf biomass. Sorting is done according to rank, to determine the best treatment. The ranking is determined by the smallest average value. The best treatment showed in BRC-AP + BRC-AK + KP. The average rating score is determined using the Kruskal-Wallis test (Table 5).

The BRC-AP isolate have the highest phosphate solubility index (27). The BRC$\mathrm{AP}$ and BRC-AK isolates were able to synergize with IAA-producer (Humicola sp .R.Dn), with the percentage of each inhibition $(-) 55.02 \%$ and (-)72\%. Giving inoculation of phosphate solubilizing bacteria and IAA-producing fungi consortium can stimulate the growth of elephant grass cuttings, especially the lengths of shoot and leaf biomass. As for root length and root biomass did not difference significant effect. The highest treatment was found in BRC-AP + BRC-AK + $\mathrm{KP}$ treatment (combination of PSB $1+\mathrm{PSB}$ 


\section{JURNAL BIDDJATI}

http://journal.uinsgd.ac.id/index.php/biodjati

$2+$ Humicola sp. R.Dn). The addition of consortium phosphate solubilizing bacteria and IAA producing fungi from South Kalimantan critical land proved can improve plant growth especially length shoot and leaf dry weight.

The results of this research show the inoculation of consortium PSB and IAA producing fungi from critical land were able to improve the growth of elephant grass cuttings, mainly growth of shoots and leaf bi- omass. It shows PSB and IAA producing fungi from critical land has potential in accelerating the efforts of critical land revegetation with elephant grass. The use of elephant grass able to prevent erosion critical land areal. So the use of consortium PSB-IAA producing fungi from critical land may become good candidates for the development of indigenous biofertilizers on critical land revegetation after further investigations.

Table 4. Root and leaf biomass elephant grass 3 weeks after planting

\begin{tabular}{lcc}
\hline \multicolumn{1}{c}{ Treatment } & Root dry weight (gram) & Leaf dry weight (gram) \\
\hline Control & $1.44 \pm 0.55 \mathrm{a}$ & $3.02 \pm 1.10 \mathrm{a}$ \\
BRC-AP & $2.12 \pm 0.39 \mathrm{a}$ & $5.34 \pm 1.53 \mathrm{~b}$ \\
BRC-AK & $1.64 \pm 0.42 \mathrm{a}$ & $4.75 \pm 1.10 \mathrm{~b}$ \\
KP & $1.63 \pm 0.54 \mathrm{a}$ & $3.9 \pm 0.88 \mathrm{ab}$ \\
BRC-AP + KP & $1.48 \pm 0.36 \mathrm{a}$ & $5.47 \pm 0.47 \mathrm{~b}$ \\
BRC-AK + KP & $1.87 \pm 0.28 \mathrm{a}$ & $4.52 \pm 0.89 \mathrm{ab}$ \\
BRC-AP + BRC-AK + KP & $1.81 \pm 0.11 \mathrm{a}$ & $5.65 \pm 0.77 \mathrm{~b}$ \\
\hline
\end{tabular}

The number followed by the same letter in the column shows no different at the $5 \%$ level of the DMRT test. (control: without the addition of inoculum). (BRC-AP: PSB isolate 1). (BRC-AK: PSB isolate 2). (KP: IAA producer isolate Humicola sp. R.Dn). BRC-AP + KP (combination of PSB $1+$ Humicola sp. R.Dn). BRC-AK + KP (combination of PSB $2+$ Humicola sp .R.Dn). BRC-AP + BRC-AK + KP (combination of PSB $1+$ PSB $2+$ Humicola sp. R.Dn)

Table 5. Ranking of treatment that spurs the growth of elephant grass cuttings

\begin{tabular}{|c|c|c|c|c|c|c|c|}
\hline \multirow{3}{*}{ Treatment } & \multicolumn{6}{|c|}{ Ranking } & \multirow{3}{*}{ Average* } \\
\hline & \multicolumn{3}{|c|}{ Shoot length } & \multirow{2}{*}{$\begin{array}{l}\text { Root } \\
\text { length }\end{array}$} & \multicolumn{2}{|c|}{ Biomass } & \\
\hline & $1 \mathrm{WAP}$ & 2 WAP & 3 WAP & & Root & Leave & \\
\hline Control & 7 & 6 & 7 & 7 & 7 & 7 & 38.5 \\
\hline BRC-AP & 3 & 2 & 4 & 1 & 1 & 3 & 11.5 \\
\hline BRC-AK & 2 & 4 & 2 & 6 & 4 & 4 & 19.5 \\
\hline KP & 6 & 5 & 5 & 3 & 5 & 6 & 27.5 \\
\hline BRC-AP + KP & 5 & 7 & 1 & 5 & 6 & 2 & 23.5 \\
\hline $\mathrm{BRC}-\mathrm{AK}+\mathrm{KP}$ & 4 & 3 & 6 & 2 & 2 & 5 & 19.5 \\
\hline $\mathrm{BRC}-\mathrm{AP}+\mathrm{BRC}-\mathrm{AK}+\mathrm{KP}$ & 1 & 1 & 3 & 4 & 3 & 1 & 10.5 \\
\hline
\end{tabular}

The average with the smallest value is the highest ranked treatment $(*=$ Average value obtained using Kruskal-Wallis test); (WAP = weeks after planting); (control: without addition of inoculum). (BRC-AP: PSB isolate 1). (BRC-AK: PSB isolate 2). (KP: IAA producer isolate Humicola sp. R.Dn).). BRC-AP + KP (combination of PSB $1+$ Humicola sp. R.Dn). BRC-AK + KP (combination of PSB $2+$ Humicola sp .R.Dn). BRC-AP + BRC-AK + KP (combination of PSB $1+$ PSB $2+$ Humicola sp. R.Dn) 


\section{JURNAL BIDDJATI}

http://journal.uinsgd.ac.id/index.php/biodjati

\section{ACKNOWLEDGMENTS}

The authors would like to thank the Directorate General of Higher Education Indonesia (DIKTI) through the Competitive Grant Program which has provided funding for this research.

\section{REFERENCES}

Ahmed, A. \& Hasnain, S. (2010). Auxin-producing Bacillus sp.: Auxin quantification and effect on the growth of Solanum tuberosum. Pure Appl. Chem., 82(1), 313-319.

Ardaka, I. M., Sudiatna, I. N. \& Hartutiningsih. (2007). Pengaruh Berbagai Media terhadap Pertumbuhan Stek Purnajiwa (Euchresta horsfieldii (Lesch.) Benth). Prosiding Seminar Konservasi Tumbuhan Usada Bali dan Peranannya dalam Mendukung Ekowisata Bali. Kebun Raya Bali 6 September 2007. Hal. 309-313. Aryantha, I. N. P., Lestari, D. P. \& Pangesti, N. P. D. ( 2004 ). Potensi Isolat Bakteri Penghasil IAA dalam Peningkatan Pertumbuhan Kecambah Kacang Hijau pada Kondisi Hidroponik. Jurnal Mikrobiologi Indonesia. 43-46.

Atekan, Nuraini Y., Handayanto, E. \& Syekhfani. (2014). The Potential of Phosphate Solubilizing Bacteria Isolated from Sugarcane Wastes for Solubilizing Phosphate. Journal of Degraded and Mining Lands Management, 1(4), 175-182.

Budi, I. S, Mariana \& Fachruzi, I. (2011). Formulasi Biopestisida Berbahan Aktif Jamur Endofitik dan Bakteri Rhizosfir Spesifik Lokasi Lahan Pasang Surut untuk Pengendalian Penyakit Busuk Pangkal Batang Padi (Rhizoctonia Solani). Prosiding Semnas Pesnab IV. Jakarta.

Egamberdiyeva, D., Jureiva, D., Pobere- jskaya, S., Myachina, O., Teryuhova, P., Seydalieva, L. \& Aliev, A. (2006). Improvement of Wheat and Cotton Growth and Nutrient Uptake by Phosphate Solubilizing Bacteria $26^{\text {th }}$ Southern Conservation .Tillage Conference 58 - 66.

Fluck, E., Heckmann, G. \& Gorbunowa-Jonas, E. (1998). Coordination Compound with 3-.4- and 6- Membered Heterocycles Containing Phosphorus. Pure \& Appl. Chem. 70(4): 819-826.

Gerhardson, B., Alstrom, S. \& Ramert, B. (2008). Plant Reactions to Inoculation of Roots with Fungi and Bacteria. Journal of Phytopathology 114, 108 - 117.

Hameeda, B., Harini, G., Rupela, O. P., Wani, S. P. \& Reddy, G. (2006). Growth Promotion of Maize by Phosphate Solubilizing Bacteria Isolated from Composts and Macrofauna. Microbiological Research 163:234-242.

Hilda, R. \& Faga, R. (2000). Phosphate Solubilizing Bacteria and Their Role in Plant Growth Promotion Departement of Microbiology. Havana Cuba: $\mathrm{Cu}-$ ban Research Institute On Sugarcane By-Products (ICIDCA).

Hussain, M. I., Asghar, H. N., Akhtar, M. J.\& Arshad, M. (2013). Impact of Phosphate Solubilizing Bacteria on Growth and Yield of Maize. Soil Environ., 32(1), 71-78.

Imaningsih, W. (2010). Potensi Cendawan Asal Serasah Tanaman Hutan sebagai Penghasil IAA (Indol Acetic Acid) dan sebagai Decomposer. Tesis. Sekolah Pasca Sarjana Institut Pertanian Bogor.

Imaningsih, W. \& Zulaikha, S. (2013). Pemanfaatan Isolat Cendawan asal Kecamatan Cempaka, Kalimantan Selatan sebagai Bioremediator Lahan Kritis. Laporan Penelitian. Universitas Lambung Mangkurat. 


\section{JURNAL BIDDJATI}

http://journal.uinsgd.ac.id/index.php/biodjati

Keesey, M. W \& Lerner, B. R. (-). General Horticulture. New Plants from Cuttings. Department of Horticulture. Purdue University Cooperative Extension Service West Lafayette, IN. Retrieved from https://ag.purdue.edu/hla/pubs/HO/HO37.pdf.

Khan, S. Md., Zaidi, A. \& Ahmad, E. (2014). Phosphate Solubilizing Microorganisms. Switzerland: Springer International Publishing.

Magcale-Macandog, D. B., Predo, C. D., Menz, K. M. \& Calub, A. D. (1998). Napier Grass Strips and Livestock: a Bioeconomic Analysis. Agroforestry Systems, 40(1), 41-58.

Malviya, J., Singh, K. \& Joshi ,V. (2011). Effect of Phosphate Solubilizing Fungi on Growth and Nutrient Uptake of Ground nut (Arachis hypogaea) Plants. Advance in Biosearch, 2(2), 110-113.

Meatyard, B. (1999). Phosphatase Enzymes from Plants : a Versatile Resource for Post-16 Courses. J. Biol. Educ., 33(2), 109-112.

Olatunji, D., Geelen, D. \& Verstraeten, I. (2017). Control of Endogenous Auxin Levels in Plant Root Development. Int. J. Mol. Sci., 18, 2587

Overvoorde, P., Fukaki, H. \& Beeckman, T. (2010). Auxin control of Root Development.Cold Spring Harbor Perspect Biol 2a001537. Cold Spring Harbor Laboratory Press.

Rao, N. S. S. (1994). Mikroorganisme Tanah dan Pertumbuhan Tanaman. Edisi Kedua. Jakarta: UI Press.

Ribnicky, D. M., Ilic, N., Cohen, J. D. \& Cooke, T. J. (1996). The Effects of Exogenous Auxins on Endogenous Indole-3-Acetic Acid Metabolism. The
Implications for Carrot Somatic Embryogenesis. Plant Physiol., 11(2), 549-558.

Santos, H. J., David, J. Jr., Garcera, A. A. \& Zuniega, R. R. (2008). Synergistic and Antagonistic Relationships of Escherichia coli, Bacillus cereus, Bacillus subtilis, Staphylococcus aureus and Penicillium notatum. General Microbiology Laboratory. University of the Philippines. Sinaga, R. (2008). Keterkaitan Nisbah Tajuk Akar dan Efisiensi Air pada Rumput Gajah dan Rumput Raja Akibat Penurunan Ketersediaan air Tanah. Jurnal Biologi Sumatra Januari, 29-35.

Skidmore, A. M. (1976). Interaction in Relation to Biological Control of Plant Pathogens. In Dickinson C H and T F Preece (Ed.) Microbiology of Serial Plant Surface. Academic Press New York, $507-528$.

Sudantha, I. M., Kusnarta, I. G. M. \& Sudana, I. N. (2011). Uji Antagonisme Beberapa Jenis Jamur Saprofit Terhadap Jamur Fusarium oxysporum F. sp. Cubense Penyebab Penyakit Layu pada Tanaman Pisang Serta Potensinya Sebagai Agens Pengurai Serasah. Agroteksos Vol 21 No 2-3. Sutatar, T. \& Sanjaya, L. (1996). Pengaruh Pemberian Zat Pengatur Tumbuh terhadap Pertumbuhan Vegetatif dan Generatif Anggrek Dendrobium Hibrid. Prosiding Seminar Nasional Tanaman Hias: Balai Penelitian Tanaman Hias.

Tam, Y. Y., Slovin, J. P. \& Cohen, J.D. (1995). Selection and Characterization of a-Methyltryptophan- Resistant Lines of Lemna gibba Showing a Rapid Rate of Indole-3-Acetic Acid Turnover. Plant Physiol., 107, 77-85. 
Jurnal Biodjati 4(1):138-148, May 2019

\section{JURNAL BIDDJATI}

http://journal.uinsgd.ac.id/index.php/biodjati

Wuriesyliane, N., Gofar, A., Madjid, H., Widjajanti, N. L. \& Putu, S. R. (2013). Pertumbuhan dan Hasil Padi pada Inseptisol Asal Rawa Lebak yang Diinokulasi Berbagai Konsorsium Bakteri Penyumbang Unsur Hara. Jurnal lahan suboptimal, 2(1), 19-28. 